\title{
THE FIELD OF STUDY AS A FACTOR DIFFERENTIATING STUDENTS' LEVEL OF ENVIRONMENTAL AWARENESS
}

Arnold Bernaciak, PhD, DSC (ORCID: 0000-0003-1099-286X) - WSB University in Poznan Anna Bernaciak, PhD (ORCID: 0000-0001-8603-1323) - Poznan University of Economics and Business

Martyna Janicka - Adam Mickiewicz University, Poznan

Correspondence address:

Powstańców Wlkp. 5, 61-895, Poznan, Poland

e-mail: arnold.bernaciak@wsb.poznan.pl

ABSTRACT: The aim of the research presented in this paper was to identify differences in environmental awareness among students of degree programmes in various fields of study. A research hypothesis was adopted stating that the field of science within which a given field of study is conducted influences students' perception of environmental problems. Based on surveys conducted using an original questionnaire among 418 students representing 106 fields of the study carried out at 44 Polish universities, within the framework of all fields of science, a number of regularities were revealed. It was shown that each of the distinguished groups of students has its own, separate characteristics. The greatest similarities can be found between the students of medical, natural and social sciences. Students of the humanities and technical sciences differ significantly from them.

KEYWORDS: environmental awareness, environmental protection, the field of study, the field of science 


\section{Introduction}

Pro-environmental attitudes and behaviour and attitudes towards environmental protection are among the issues that largely reflect generational differences. One of the main reasons for such a discrepancy is when environmental issues have become widespread. The visible effects of environmental devastation on the one hand, and the emergence of environmental movements publicising environmental problems on the other, have contributed to this.

The very concept of 'environmental awareness' is not defined unambiguously. Thus, first of all, broader and narrower approaches are distinguished (Hull, 1984; Domka, 1998; Papuzinski, 2006; Poskrobko, 2007), it is also analysed in relation to basic types of cognition (Gorka, Poskrobko, Radecki, 2001) and its structural and substantive features are also indicated (Cherdymova et al. 2018).

The most common definitions of environmental awareness in the literature emphasise its following components:

- knowledge: "knowledge among actors in an ecological community of the role of organisations as one class of members in the natural environment whose actions have the potential to affect every class of members' (Strong, 1996), 'a set of information and beliefs about the natural environment and the perception of relations between the state and nature of the natural environment and human living conditions and quality of life' (Burger, 1986),

- awareness: 'a form of social consciousness that is reflected in the experiences and thinking of individuals and socially functioning norms for understanding and valuing the natural environment' (Frątczak, 1995),

- information and beliefs: 'information and beliefs about the natural environment and the perception of links between the state and the character of the natural environment and the conditions and the quality of human life' (Prévot-Julliard et al., 2011),

- perception: 'seeing and appreciating the importance of the relation between the economic activities of society and the process of devastation and degradation of nature' (Papuzinski, 2006),

- attitudes: 'a person's attitude towards the natural environment, a set of information and beliefs about it, as well as the value system that this person is guided by towards it in his/her behaviour' (Kiełczewski, 2001).

Ecological awareness in a broad sense is the totality of recognised ideas, values, opinions about the environment as the place of human (society) life and development shared by defined social groups in a particular historical period comprises all internalised ideas, values and opinions about the envi- 
ronment as the place of human (social) life and development shared by defined groups in a particular historical period. In a narrower sense it is defined as the state of knowledge, opinions and beliefs people share about the role of the environment in human life, the degree of exploitation, hazard and protection including the state of knowledge about measures and instruments of environmental management (Jaska, 2009). As its components indicated are:

- environmental attention: the concentration of consciousness on a certain natural object or phenomenon, which provides a particularly clear reflection of it,

- environmental memory: associated with a number of complicated mental processes actively mastering which a person manages the acquisition and preservation in the mind of useful information about natural objects (phenomena), its reproduction at the right time,

- environmental perception: the perception by the consciousness of signals coming from objects of nature (animals, plants) and natural phenomena (such as rainfall),

- environmental affect: states of pleasure or displeasure associated with perceptions, emotions, feelings, and passions, thoughts caused by natural objects or phenomena,

- environmental thinking: concentrates three types of thinking - aimed at finding the single best solution to the problems encountered in the natural environment, aimed at finding many possible solutions to the problem associated with nature and characterised by originality and ingenuity of possible solutions to natural objects and phenomena (Cherdymova, 2011; Cherdymowa et al., 2018).

According to Mirowski (1996), ecological awareness consists of ecological knowledge expressed through the acquaintance with and understanding of the means of coexistence between man and nature, ecological sensitivity, or emotional attitude to nature and pro-ecological attitude, or actions undertaken to protect the natural environment. Partanen-Hertell et al. (1999) indicate motivation, knowledge and skills as components of environmental awareness.

Among the sources of environmental awareness primarily indicated are educational institutions (family, school, workplace), mass media and social experience. The factors shaping environmental awareness are divided into subjective and objective. The former include 'the properties of the individual, related to his general psychic structure (intellect, emotional system). The latter include such phenomena as the conditions of existence (economic, political, cultural) and the activity of state institutions and social groups aimed at the direct shaping of consciousness' (Szulborski, 2001). 
The above definitions and ways of understanding and describing environmental awareness indicate that it is a complex concept, manifested in different dimensions, although at the same time rooted in society and reflected in specific attitudes. The determinant of ecological awareness, in its broadest sense, is primarily respect for the surrounding nature, adherence to the principles of environmental protection, and also counteracting threats.

\section{Literature Review - ecological awareness of society and students}

Research on environmental awareness is of interest to many disciplines and fields of science, as well as practitioners, including authorities at various levels and third sector actors. Studies relating to whole societies (including cyclical studies) are often conducted (Kłos, 2015; Ministerstwo Środowiska i Klimatu, bd.; Badania świadomości i..., 2020; Rosa, Collado, \& Profice, 2018), as well as comparative studies between countries and societies using various data from public statistics and authors own research ideas (Schultz and Zelezny, 1999; Gleissen, 2007; Marquart-Pyatt, 2007; Mostafa, 2012; Franzen and Vogl, 2013; Kokkinen, 2014; Harju-Autti and Kokkinen, 2014; Rydzewski, 2016; Pisano and Lubell, 2017; Chen et al., 2019). The results of most studies show that respondents describe the state of the environment as unsatisfactory and constantly deteriorating, while at the same time, their awareness of tools and ways to care for the environment is increasing. For example, in surveys covering Poland, over $96 \%$ of respondents declare that they regularly segregate waste. According to $94 \%$ of respondents, climate change is an important or very important problem. More than three-quarters of Polish residents are willing to spend more on 'clean' energy, and nearly 6 in 10 plan to change their furnace to a more environmentally friendly energy source. Moreover, the most frequently indicated reason for protecting the environment is a concern for future generations, and seven out of ten Poles consider climate change to be a severe problem (Badania świadomości i..., 2020).

Students are a particularly frequently surveyed group in this regard. This may be due to the fact that for some researchers they are a natural group on which it is possible to test certain research methods and assumptions. Some researchers also emphasise that students are a group that in the near future will be important in terms of shaping the attitudes of other members of society - as parents, teachers or people functioning in the work environment, performing decision-making functions or otherwise influencing the environment (Abbas and Singh, 2014). 
Among students, both their general attitudes towards environmental issues and their environmental awareness are analysed (Wong, 2003; Kryk, 2007; Ozil et al. 2008; Oğuz, 2010; Abbas and Singh, 2014; Maravic, Cvjeticanin and Ivkovic, 2014; Kłos, 2014; Moryń-Kucharczyk, 2016; Amérigo et al., 2017; Mohiuddin et al. 2018; Boca and Saraçli, 2019; Arshad et al., 2021), as well as awareness about functioning of specific environmental components or attitudes towards specific issues (Chen and Tsai, 2016; Kazakova et al., 2020). The general conclusion of the research is that the level of awareness among students changes over time and is strongly correlated with the country in which the research is conducted and factors that include the field of study, gender, age, material status or place of residence.

Another interesting strand of research is the analysis of changes in the pattern and content of education or changes in the curriculum, as well as the use of innovative technologies and determining the impact of the actions are taken on students' attitudes and behaviour (Capdevila et al., 2002; Uzunboylu et al., 2009). This issue is directly related to the 'green-curriculum' trend that developed especially in the early 2000s and its implementation at different levels of education (Haigh, 2005; Wang et al., 2013; Louw, 2013; Xiong et al., 2013; Bernaciak and Kozłowska, 2017). Most studies emphasise the importance of environmental content and changing the approach to how students are educated.

\section{Materials and Methods}

The research aimed to identify differences in environmental awareness among students of degree programmes in various fields of study. A research hypothesis was adopted stating that the field of science within which a given field of study is conducted influences students' perception of environmental problems. Differentiation is revealed in the assessment of own knowledge concerning the environment, assessing the level of contemporary ecological threats, individual pro-ecological activity, and evaluating the importance of individual pro-ecological activities.

It was assumed that students' environmental awareness is differentiated by several formal and non-formal conditions specific to the field of study. The former include elements of education: the type and nature of the knowledge taught, the skills acquired, and the attitudes formed during the studies. The latter includes all activities undertaken by students outside the study time, which may have an impact on their individual knowledge and attitudes, including, e.g., individual interests, interests of other persons from student groups, contacts with lecturers, discussions undertaken in student groups, 
additional classes, voluntary work, work. Formal and non-formal factors create an atmosphere characteristic of a given field of study, influencing the formation of environmental awareness. The fields of study realised within a given discipline show some similarity in terms of formal and non-formal factors, which enables their aggregation for the analyses conducted.

Assuming the above-mentioned assumptions, a comparative analysis between the groups of fields of study was carried out within individual fields of science was conducted. The aggregation of fields of study was made by classifying them into one of the five areas: humanities, technical sciences, medical sciences, natural sciences, and social sciences. Students of faculties related to arts were included in the field of humanities, while students of agricultural faculties were included in the field of technical sciences. Mathematics students were included in the natural sciences.

The conducted research had a pilot character. It covered 418 students representing 106 fields of study at 44 Polish universities in all fields of science (table 1$)^{1}$. The diagnostic survey was conducted from 4 to 31 March 2021.

Table 1. Size of the research sample in particular groups

\begin{tabular}{lll}
\hline Item No. & Field of science & Number of respondents \\
\hline 1. & Humanities (including arts) & 50 \\
\hline 2. & Technical sciences (including agricultural sciences) & 52 \\
\hline 3 & Medical sciences & 72 \\
\hline 4. & Life sciences & 37 \\
\hline 5. & Social sciences & 207 \\
\hline Total & & 418 \\
\hline
\end{tabular}

Source: authors' work.

The research was performed with the use of the CAWI method. The subject of the research was ecological awareness and its components: knowledge and attitudes. An original survey form was used in which 11 questions

1 The total number of students in Poland at the end of 2019, according to Central Statistical Office data, was 1.2 million (in public and private schools in total). Due to the inability to obtain data on the entire population and to perform the sampling frame, the selection of the sample was deliberate. The structure of the sample by fields of study is somewhat similar to the structure of the population $-47.9 \%$ of students study social sciences in Poland (50\% in our study), $10 \%$ humanities including arts (12\% in our study), $22.6 \%$ technical sciences including agriculture $(12 \%$ in our study), $3.8 \%$ life sciences ( $9 \%$ in our study), $11.5 \%$ medical sciences $(17 \%$ in our study). 
were asked. Questions asked were concerning: 1) assessment of own knowledge in the field of ecology and environmental protection, 2) assessment of the state of the natural environment, 3 ) the greatest contemporary threats to the environment, 4) sources of knowledge in the field of ecology and environmental protection, 5) taking action to protect the environment, 6) motivation to take action, 7) type of action taken 8) assessment of the actual impact of action taken on the state of the environment, 9) reasons for not taking action to protect the environment 10 ) readiness to lower the level of quality of life for environmental reasons and 11) readiness to limit tourist trips.

\section{Results of the research}

Students rather positively assess the level of their knowledge about the environment - 52\% assess it as good or very good, and $46 \%$ describe it as moderate (figure 1). There is a big difference between the assessments made by students from different fields of study. It is best rated by students of natural sciences, whereas many as 73\% consider its level as good or very good. Nobody in this group assesses the level of their knowledge as bad or very bad. However, what is surprising is the moderate assessment of knowledge in the field of ecology and environmental protection by students of medical and technical faculties. Among the latter, even 4\% assess this knowledge as 'bad'. Humanists rate their knowledge very similarly. Against this background, the assessment made by students of social sciences, who have the least connection with the content of ecology and environmental protection, is very interesting. In this case, the majority, as many as 55\%, of students assess their knowledge well or very well.

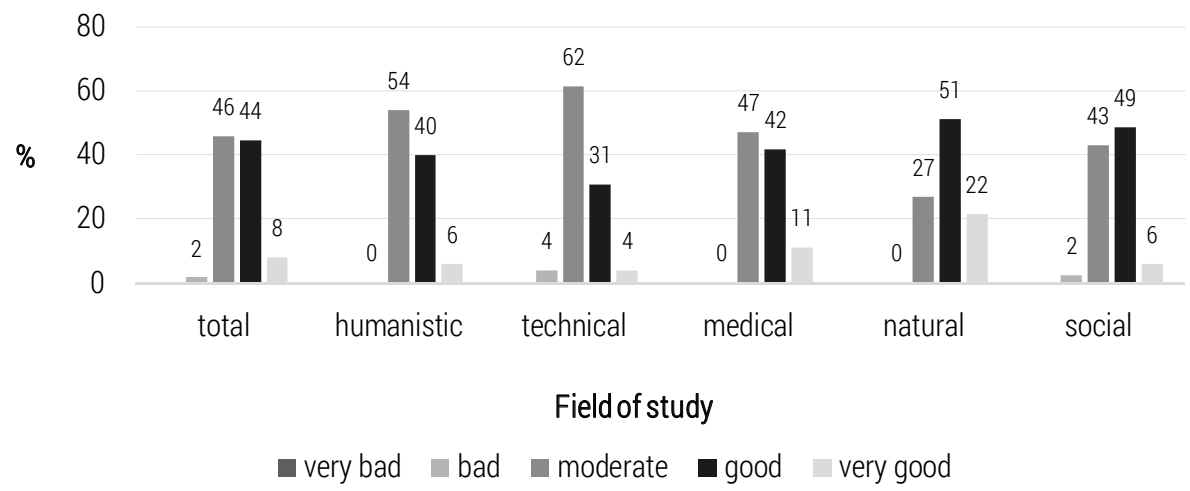

Figure 1. Assessment of knowledge in the field of ecology and environmental protection Source: authors' work. 
The basic source of knowledge for the respondents is the information available on the Internet (table 2). Social media (75\% of indications) and online articles and podcasts reach (72\%) a definite advantage over other, traditional sources of information. It is worth noting that scientific journals are used to gain knowledge about the state of the environment and its protection by only $27 \%$ of the students surveyed. Apart from the previously mentioned Internet sources, films and TV programmes are more popular than scientific magazines. School education also has more indications.

News via social media is the primary source for students in the humanities (95\%), technology (69\%) and medicine (69\%). On the other hand, online articles and podcasts are the main sources of information for students in the natural sciences $(73 \%)$ and social sciences (76\%). It is important to note the relatively high importance attached to classical sources of knowledge by natural science students. In this group, school education (51\%), scientific journals (41\%) and conferences (24\%) are significantly more indicated than in the other groups. Students of technical sciences also attach great importance to school education, where as much as $62 \%$ indicate it as a source of knowledge about the environment and its condition.

Table 2. Sources of knowledge about ecology and the state of the environment (\% of indications)

\begin{tabular}{lllllll}
\hline Source & Total & Humanistic & Technical & Medical & Natural & Social \\
\hline School education & 40 & 20 & 62 & 31 & 51 & 41 \\
\hline TV programmes & 45 & 44 & 56 & 35 & 32 & 48 \\
\hline Educational films & 45 & 50 & 48 & 43 & 43 & 44 \\
\hline Radio programmes & 10 & 8 & 12 & 13 & 3 & 11 \\
\hline Advertisements & 18 & 18 & 29 & 14 & 5 & 14 \\
\hline Leaflets & 6 & 8 & 12 & 7 & 3 & 5 \\
\hline Information brochures & 14 & 20 & 13 & 14 & 11 & 13 \\
\hline Posters/Billboards & 19 & 18 & 31 & 15 & 3 & 20 \\
\hline Internet article/podcasts & 72 & 80 & 62 & 63 & 73 & 76 \\
\hline Scientific journals & 27 & 24 & 27 & 35 & 41 & 22 \\
\hline $\begin{array}{l}\text { Conferences/information meetings/ } \\
\text { training sessions }\end{array}$ & 12 & 10 & 12 & 8 & 24 & 12 \\
\hline Social media & 75 & 94 & 69 & 69 & 65 & 75 \\
\hline
\end{tabular}

Source: authors' work. 
The assessment of the state of the environment is dominated by the categories bad and very bad. This is how it is perceived by $73 \%$ of respondents (figure 2). Students of humanities are the most critical in their assessments, where the condition of the environment is perceived in these categories by as many as $94 \%$ of the respondents. On the other hand, students of technical sciences are least pessimistic about the environment. In this case, its condition is described as bad or very bad by 'only' $58 \%$ of students, and as many as $10 \%$ perceive it as good (6\%) or very good (4\%). It is worth noting that in the case of students from other disciplines, no one describes the state of the environment as 'very good', and only $3 \%$ of students from social sciences assess it as good. In the case of students from other disciplines, the results are similar. The bad or very bad state of the environment is indicated by $78 \%$ of students of medical and natural sciences and $70 \%$ of students of social sciences.

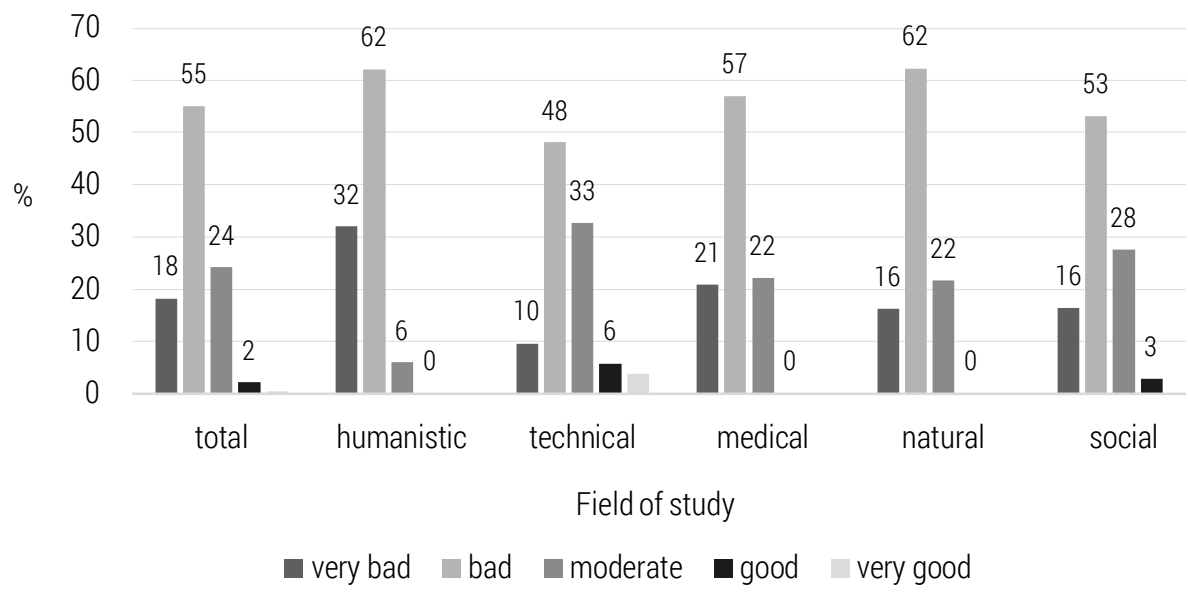

Figure 2. Assessment of the condition of the environment

Source: authors' work.

Assessments of the greatest contemporary threats to the environment are very similar (table 3). Respondents clearly indicated water and air pollution (85\%). Bad waste management comes second (69\%) and deforestation third (64\%).

The vast majority of students declare that they take action in their everyday life to protect the environment. In total, it is $87 \%$ of respondents. The results of most of the surveyed groups are around $90 \%$. The exception is students of technical sciences, where 'only' $67 \%$ of respondents declare taking such actions. 
Table 3. Most important threats to the environment (\% of indications)

\begin{tabular}{|c|c|c|c|c|c|c|}
\hline Category & Total & Humanistic & Technical & Medical & Natural & Social \\
\hline Deforestation & 64 & 70 & 60 & 64 & 65 & 63 \\
\hline Mineral resources extraction & 38 & 34 & 33 & 39 & 32 & 41 \\
\hline Loss of natural habitats & 50 & 50 & 42 & 57 & 54 & 48 \\
\hline Water and air pollution & 85 & 86 & 90 & 78 & 81 & 86 \\
\hline Poor waste management & 69 & 72 & 73 & 63 & 62 & 71 \\
\hline Cultivation and breeding of GMOs & 5 & 2 & 10 & 7 & 3 & 5 \\
\hline Consumer lifestyle & 62 & 68 & 46 & 68 & 73 & 61 \\
\hline $\begin{array}{l}\text { Low level of environmental } \\
\text { education }\end{array}$ & 40 & 42 & 33 & 35 & 46 & 42 \\
\hline
\end{tabular}

Source: authors' work.

The most popular pro-ecological activities undertaken by students include waste segregation, using reusable bags and taking care of green infrastructure (table 4).

Table 4. Pro-environmental actions taken (\% indications)

\begin{tabular}{lllllll}
\hline Category & Total & Humanistic & Technical & Medical & Natural & Social \\
\hline Waste segregation & 76 & 84 & 56 & 83 & 73 & 76 \\
\hline Use of reusable bags & 77 & 84 & 60 & 83 & 73 & 78 \\
\hline Taking care of greenery & 68 & 84 & 50 & 72 & 68 & 68 \\
\hline Choosing reusable products & 57 & 72 & 40 & 64 & 62 & 54 \\
\hline Saving water & 64 & 64 & 50 & 61 & 70 & 67 \\
\hline Saving energy & 49 & 64 & 35 & 44 & 51 & 50 \\
\hline Use of energy-efficient products & 61 & 62 & 54 & 64 & 41 & 65 \\
\hline Use of public transport & 45 & 50 & 25 & 56 & 49 & 44 \\
\hline $\begin{array}{l}\text { Choosing products with biodegra- } \\
\text { dable packaging }\end{array}$ & 16 & 40 & 12 & 44 & 22 & 0 \\
\hline Cycling & 22 & 18 & 15 & 24 & 24 & 24 \\
\hline Choosing natural cleaning products & 15 & 18 & 8 & 19 & 22 & 14 \\
\hline Following the 'zero waste' principle & 18 & 16 & 6 & 25 & 19 & 18 \\
\hline
\end{tabular}

Source: authors' work. 
Moreover, students of natural sciences pay much attention to saving water, while technical faculties pay much attention to using energy-efficient products. Perhaps surprisingly, a relatively small percentage of students use a bicycle as a means of transport (22\%). On the other hand, twice as many indicate public transportation as a way to get around town. Also, relatively unpopular among students are: choosing natural cleaning products, choosing products with biodegradable packaging and avoiding waste, following the 'zero waste' principle.

People undertaking activities aimed at environmental protection are rather sceptical about their actual positive influence on the natural environment. This influence is assessed as small or very small by $37 \%$ of respondents and as large or very large by $31 \%$ (figure. 3 ).

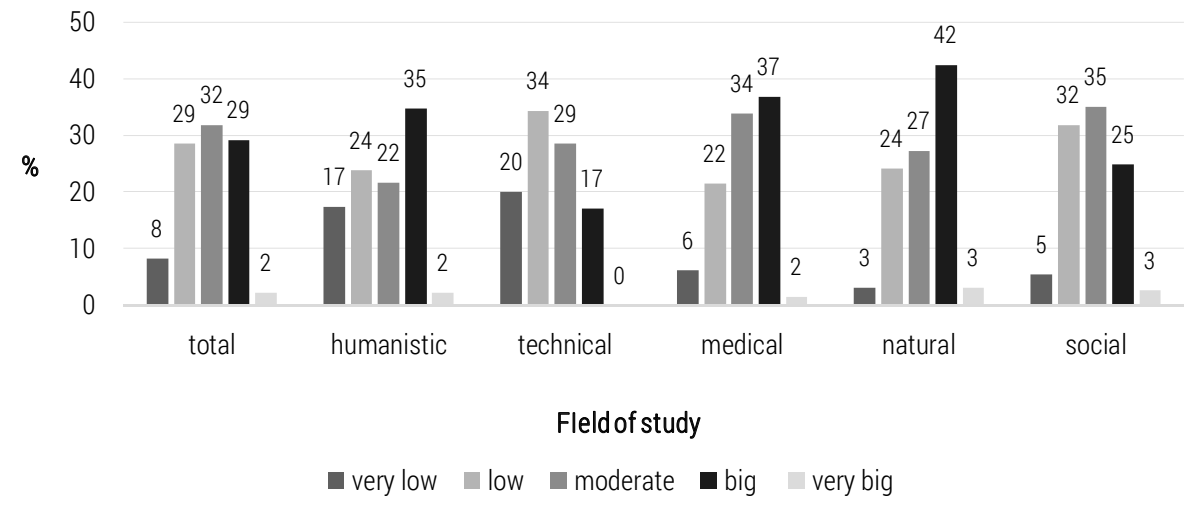

Figure 3. Assessment of the actual impact on the environment of the undertaken proenvironmental activities

Source: authors' work.

Students of natural sciences and medical faculties should be perceived as optimists in this respect. In these groups, the percentage of those assessing the impact of their actions as large and very large exceeds the percentage of those assessing it as small or very small. In the case of natural science students, the difference between these ratings is 18 percentage points and in the case of medical students, 11 percentage points. The opposite situation is recorded for the other student groups. Students of technical subjects show the greatest scepticism. The difference between the sum of marks for the categories bad and very bad and great and very good is as much as 37 percentage points favouring the former. In the case of social science students, the difference is 10 percentage points, and in the humanities, it is 4 percentage points. 
When analysing the issue of not taking protective measures - students perceive that the reasons for this lie primarily in themselves, and to a lesser extent, in external factors (table 5). First of all, they indicate the fast and comfortable lifestyle (72\%) and the associated difficulty in changing habits $(65 \%)$. As the cause, they also perceive insufficient knowledge about the state of the environment and its protection (66\%) and the belief that individual actions are not effective in achieving protection goals (61\%). Much less indicated are reasons that can be considered external: lack of inspiration and motivation from the authorities (42\%), high costs of pro-environmental activities (35\%) or lack of possibilities to undertaking such activities (12\%).

Table 5. Reasons for not taking up pro-ecological activities (\% of indications)

\begin{tabular}{|c|c|c|c|c|c|c|}
\hline Category & Total & Humanistic & Technical & Medical & Natural & Social \\
\hline $\begin{array}{l}\text { Little knowledge of the state of } \\
\text { the environment and ways of } \\
\text { protecting it }\end{array}$ & 66 & 72 & 46 & 65 & 73 & 68 \\
\hline $\begin{array}{l}\text { Belief that individual action is not } \\
\text { effective }\end{array}$ & 61 & 78 & 67 & 32 & 68 & 64 \\
\hline Fast and convenient lifestyle & 72 & 70 & 67 & 74 & 73 & 73 \\
\hline $\begin{array}{l}\text { Belief in high costs of taking } \\
\text { action }\end{array}$ & 35 & 32 & 27 & 67 & 27 & 29 \\
\hline Inability to take action & 12 & 14 & 8 & 18 & 19 & 10 \\
\hline $\begin{array}{l}\text { Lack of initiative and motivation } \\
\text { on the part of the authorities }\end{array}$ & 43 & 44 & 44 & 51 & 30 & 42 \\
\hline Difficulties in changing habits & 65 & 66 & 67 & 67 & 70 & 63 \\
\hline
\end{tabular}

Source: authors' work.

The surveyed students declare their consent to a potential decrease in the quality of life if it would be necessary to protect the environment from further degradation. Such attitude is characteristic of $67 \%$ of the surveyed (figure 4). In this case there is also quite a large variation between the particular groups surveyed. The highest percentage of people willing to make such a sacrifice is found in the group of medical science students $-76 \%$ and among humanists - 74\%. At the other extreme are students of natural sciences and engineering, among whom readiness to reduce the quality of life for environmental reasons is declared by $54 \%$ and $56 \%$, respectively.

The situation is reversed in the case of declarations concerning willingness to limit tourist trips to one every five years due to environmental protection. Only $33 \%$ of respondents declare such willingness (fig. 5). In this case, we can also observe differentiation between particular groups. The least 
willing to make such a sacrifice are students of social sciences (26\%) and medical sciences (32\%). The largest group of people willing to make such a challenge is found among natural sciences students (54\%).

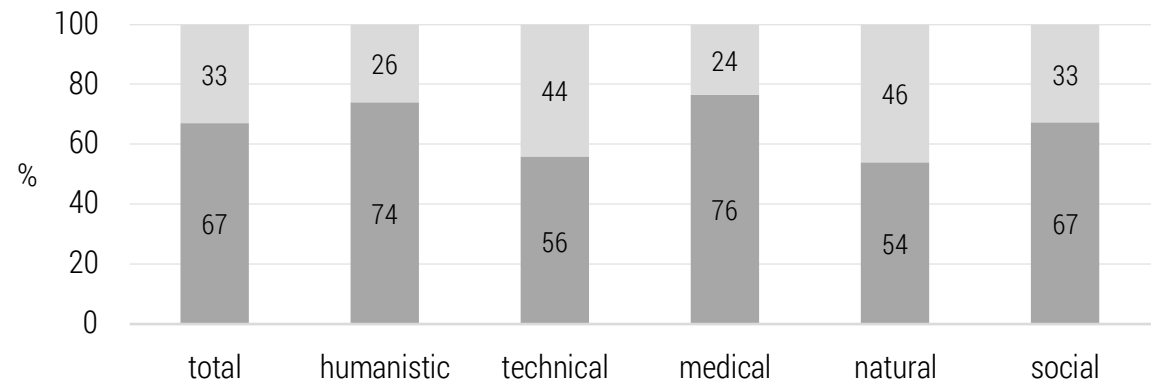

Figure 4. Readiness to lower the quality of life due to environmental protection Source: authors' work.

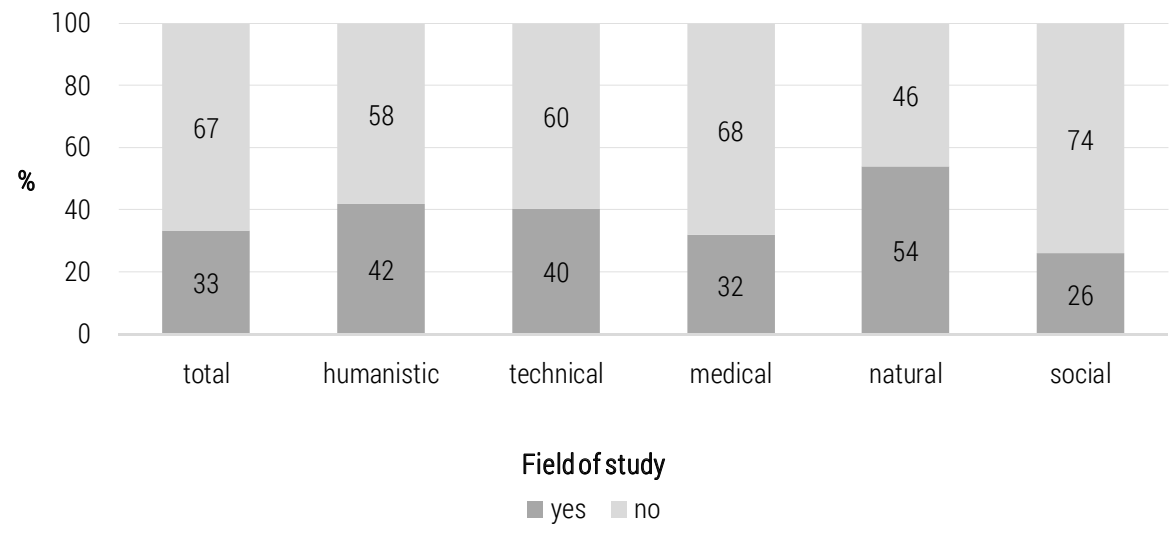

Figure 5. Readiness to limit holiday trips due to environmental protection Source: authors' work.

In conclusion, it is worth pointing out the differences in environmental awareness revealed between students of majors pursued in different fields of science. Each of the distinguished groups of students has its own, separate characteristics. The greatest similarities can be found between the students of medical, natural, and social sciences. Students of the humanities and technical sciences differ significantly from them (table 6). 
Table 6. Generalised characteristics of students' environmental awareness - comparison by field of study

\begin{tabular}{llllll}
\hline Category & Humanistic & Technical & Medical & Natural & Social \\
\hline $\begin{array}{l}\text { Environmental knowledge } \\
\text { (declaration) }\end{array}$ & Average & Little & Average & High & Average \\
\hline $\begin{array}{l}\text { Assessment of the condition } \\
\text { of the environment }\end{array}$ & Very bad & Moderate & Bad & Bad & Bad \\
\hline Sources of knowledge & Modern & $\begin{array}{l}\text { Modern/ } \\
\text { traditional }\end{array}$ & Modern & $\begin{array}{l}\text { Modern/ } \\
\text { traditional }\end{array}$ & Modern \\
\hline Taking action (declaration) & Yes & Yes/no & Yes & Yes & Yes \\
\hline Readiness to sacrifice & Very high & Average & High & High & Average \\
\hline
\end{tabular}

Source: authors' work.

Students of the humanities are characterised by a moderate assessment of their knowledge of ecology and a very pessimistic view of the current state of the environment. They draw their knowledge in this area almost exclusively from modern sources. They declare undertaking many pro-ecological activities and high readiness to make sacrifices for the environment.

Students of technical faculties estimate their knowledge about the environment rather low, not having at the same time a very negative assessment of its current state. They use modern sources of knowledge to a large extent, but they also appreciate the role of traditional sources. They are not eager to undertake pro-environmental activities, and their willingness to sacrifice in this respect is not particularly high.

Medical students declare an average level of knowledge about the environment. They perceive the bad condition of ecosystems. They gain knowledge in this area mainly from modern sources. They declare taking pro-ecological actions and express a high willingness to sacrifice. Awareness similar to medical students characterises students of natural sciences. The difference between them lies primarily in the latter's declared greater knowledge of the environment and their wider use of traditional sources of knowledge.

Students of social sciences are also similar to students of medical and natural sciences in the scope in question. In this case, however, the level of willingness to sacrifice for the environment is lower. 


\section{Summary}

Ecological awareness in a broad sense is the totality of recognised ideas, values, opinions about the environment as a place of life and development of a human (society), common for specific social groups in a given historical period, and one of its key components is knowledge. Its acquisition may be formal - through the acquisition of information in the course of education, acquisition of skills and shaping of attitudes within the educational process. At the same time, it is possible to acquire knowledge in an informal way through all activities undertaken outside the time of learning, which may affect individual knowledge and attitudes. For the purposes of the study, it was assumed that students' environmental awareness is differentiated by a number of formal and non-formal conditions specific to the field of study, and the hypothesis posed was that the area of science within which a particular field of study is conducted influences students' perceptions of environmental problems.

It was shown that differentiation is revealed in the assessment of their knowledge of the environment, assessment of the level of contemporary environmental threats, individual pro-ecological activity, assessment of the importance of individual pro-ecological activities undertaken, which was revealed in the observation that each of the distinguished groups of students has its own distinct characteristics. The greatest similarities can be found between the students of medical, natural, and social sciences. Students of the humanities and technical sciences differ significantly from them. Other results indicate that students rather positively assess the level of their knowledge about the environment, although they derive this knowledge from different sources. On the other hand, they negatively assess the state of the environment and identify manifestations of this fact in similar areas. The vast majority of students declare taking actions in their daily lives aimed at protecting the environment and declare their consent to a potential reduction in the level of their quality of life if this would be necessary to protect the environment from further degradation, although, in the case of an unambiguous declaration concerning the readiness to limit tourist trips, to one in five years, due to environmental protection, they are mostly not ready to make concessions.

The pilot study has revealed a number of regularities that require further verification in research involving a wider group. It also seems interesting to undertake research involving students from other countries, including countries from other cultural circles. 


\section{The contribution of the authors}

Arnold Bernaciak: conception $-60 \%$, literature review $-10 \%$, acquisition of data $10 \%$, analysis and interpretation of data $-70 \%$

Anna Bernaciak: conception - 20\%, literature review $-80 \%$, acquisition of data $10 \%$, analysis and interpretation of data $-20 \%$

Martyna Janicka: conception - 20\%, literature review - 10\%, acquisition of data $90 \%$, analysis and interpretation of data $-10 \%$

\section{References}

Abbas, M. Y., Singh, R., 2014. A survey of environmental awareness, attitude, and participation amongst university students: A case study. International Journal of Science and Research, 3(5), 1755-1760.

Amérigo, M., García, J. A., Côrtes, P. L., 2017. Analysis of environmental attitudes and behaviours: An exploratory study with a sample of Brazilian university students. Ambiente \& Sociedade, 20(3), 1-20, https://doi.org/10.1590/1809-4422 ASOC300R1V2032017.

Amérigo, M., Palavecinos, M., García, J. A., Román, F., Trizano-Hermosilla, Í., 2017. Effects of the social dominance orientation on environmental attitudes of Chilean university students/Efectos de la orientación a la dominancia social sobre las actitudes ambientales de universitarios chilenos. Revista de Psicología Social, 32(1), 136-163, https://doi.org/10.1080/02134748.2016.1248023.

Arshad, H. M., Saleem, K., Shafi, S., Ahmad, T., Kanwal, S., 2021. Environmental Awareness, Concern, Attitude and Behavior of University Students: A Comparison Across Academic Disciplines. Polish Journal of Environmental Studies, 30(1), 561-570, https://doi.org/10.15244/pjoes/122617.

Badania świadomości i zachowań ekologicznych mieszkańców Polski w 2020 r. (badania trackingowe) https://www.gov.pl/web/klimat/badania-swiadomosci-i-zachowan-ekologicznych-mieszkancow-polski-w-2020-r-badanie-trackingowe (26.03.2020).

Bernaciak, A., Kozłowska, A., 2017. Using Innovative Teaching Methods to Promote Sustainable Development among Students of Economics and Management. Studia Periegetica, 17, 21-33.

Boca, G. D., Saraçlı, S., 2019. Environmental education and student's perception, for sustainability. Sustainability, 11(6), https://doi.org/10.3390/su11061553.

Burger, T., 1986. Uwagi o świadomości ekologicznej. Przegląd Powszechny, 12, 374388.

Capdevila, I., Bruno, J., Jofre, L., 2002. Curriculum greening and environmental research co-ordination at the Technical University of Catalonia, Barcelona. Journal of Cleaner Production, 10(1), 25-31, https://doi.org/10.1016/S0959-6526(01) 00019-1.

Chen, C. L., Tsai, C. H., 2016. Marine environmental awareness among university students in Taiwan: a potential signal for sustainability of the oceans. Environmental Education Research, 22(7), 958-977, https://doi.org/10.1080/13504622.20 15.1054266. 
Chen, X., Huang, B., Lin, C. T., 2019. Environmental awareness and environmental Kuznets curve. Economic Modelling, 77, 2-11, https://doi.org/10.1016/j.econmod.2019.02.003.

Cherdymova E.I., 2011. Environmental consciousness (both theoretical and empirical research). Samara: Publishing house.

Cherdymova, E.I., Afanasjeva, S.A., Parkhomenko, A.G., Ponyavina, M.B., Yulova, E.S., Nesmeianova, I.A., Skutelnik, O.A., 2018. Student ecological consciousness as determining component of ecological-oriented activity. EurAsian Journal of BioSciences, 12(2), 167-174.

Domka, L., 1998. Kryzys środowiska a edukacja dla ekorozwoju, Wyd. Naukowe UAM, Poznań.

Franzen, A., \& Vogl, D., 2013. Two decades of measuring environmental attitudes: A comparative analysis of 33 countries. Global Environmental Change, 23(5), 1001-1008, http://dx.doi.org/10.1016/j.gloenvcha.2013.03.009.

Frątczak, J., 1995. Świadomość ekologiczna dzieci, młodzieży i dorosłych w aspekcie edukacji szkolnej i nieszkolnej. Wyższa Szkoła Pedagogiczna w Bydgoszczy.

Gliński, P., 1988. Świadomość ekologiczna społeczeństwa polskiego - dotychczasowe wyniki badań. Kultura i społeczeństwo, 32(3),189-190.

Górka, K., Poskrobko, B., \& Radecki, W., 2001. Ochrona środowiska. PWE, Warszawa.

Haigh, M., 2005. Greening the university curriculum: Appraising an international movement. Journal of Geography in Higher Education, 29(1), 31-48, https://doi. org/10.1080/03098260500030355.

Harju-Autti, P., Kokkinen, E., 2014. A Novel Environmental Awareness Index Measured Cross-Nationally For Fifty Seven Countries. Universal Journal of Environmental Research \& Technology, 4(4).

Hull, Z., 1984. Świadomość ekologiczna. Aura, 11, 24-25.

Jaska, E., 2009. Ecological awareness of the society and sustainable development. Roczniki Naukowe Stowarzyszenia Ekonomistów Rolnictwa i Agrobiznesu, 11(6), 56-61.

Kazakova, O. M., Malinovskaia, T. N., Fedulov, B. A., Romanova, E. V., Zavgorodnii, A. G., Matveychuk, N. S., 2020. Ecological awareness of university students about UN sustainable development goals at global, national and regional levels. Ukrainian Journal of Ecology, 10(1), http://dx.doi.org/10.15421/2020_34.

Kiełczewski D., 2001. Ekologia społeczna (Social ecology). Wydawnictwo Ekonomia i Środowisko, Białystok.

Kłos, L., 2014. Wiedza i świadomość ekologiczna studentów. Prace Naukowe Uniwersytetu Ekonomicznego we Wrocławiu (330), 182-191.

Kłos, L., 2015. Świadomość ekologiczna Polaków-przegląd badań. Studia i Prace WNEiZ US, (42/2), 35-44, http://dx.doi.org/10.18276/sip.2015.42/2-03.

Kokkinen, E., 2013. Measuring environmental awareness in the world. University of Oulu: Oulu, Finland.

Kryk, B., 2007. Świadomość ekologiczna studentów-prawda czy fikcja Prace Naukowe Akademii Ekonomicznej we Wrocławiu, 1185, Gospodarka a Środowisko, 7, 48-60, http://dx.doi.org/10.15611/pn.2016.453.20.

Louw, W., 2013. Green curriculum: Sustainable learning at a higher education institution. International Review of Research in Open and Distributed Learning, 14(1), 1-15, https://doi.org/10.19173/irrodl.v14i1.1310. 
Maravic, M., Cvjeticanin, S., \& Ivkovic, S., 2014. Level of environmental awareness of students in republic of Serbia. World Journal of Education, 4(3), 13-18, https:// doi.org/10.5430/wje.v4n3p13.

Marquart-Pyatt, S. T., 2007. Concern for the environment among general public: A cross-national study. Society \& Natural Resources, 20(10), 883-898, http:// dx.doi.org/10.1080/08941920701460341.

Ministerstwo Środowiska i Klimatu, Badania świadomości ekologicznej, https:// www.gov.pl/web/klimat/badania-swiadomosci-ekologicznej (26.03.2021).

Mirowski, W., 1996. Environmental awareness and sustainability. Issues of Science Studies, 3, 10-15.

Mohiuddin, M., Al Mamun, A., Syed, F. A., Mehedi Masud, M., \& Su, Z., 2018. Environmental knowledge, awareness, and business school students' intentions to purchase green vehicles in emerging countries. Sustainability, 10(5), 1534, https:// doi.org/10.3390/su10051534.

Moryń-Kucharczyk, E., 2016. Edukacja i świadomość ekologiczna studentów uczelni technicznych. Edukacja-Technika-Informatyka, 7(2), 264-271. https://doi.org/ 10.15584/eti.2016.2.35.

Mostafa, M. M., 2012. Does globalisation affect consumers' pro-environmental intentions? A multilevel analysis across 25 countries. International Journal of Sustainable Development \& World Ecology, 19(3), 229-237, https://doi.org/10.1080/ 13504509.2011 .614289$.

Oğuz, D., Kavas, S., 2010. Environmental awareness of university students in Ankara, Turkey. African Journal of Agricultural Research, 5(19), 2629-2636.

Ozil, E., Ugursal, V. I., Akbulut, U., Ozpinar, A., 2008. Renewable energy and environmental awareness and opinions: A survey of university students in Canada, Romania, and Turkey. International Journal of Green Energy, 5(3), 174-188, https://doi.org/10.1080/15435070802107025.

Palmer, J. A., Suggate, J., Bajd, B., KP, P. H., Ho, R. K., Ofwono-Orecho, J. K. W., Staden, C. V., 1998. An overview of significant influences and formative experiences on the development of adults' environmental awareness in nine countries. Environmental education research, 4(4), 445-464, https://doi.org/10.1080/135046298 0040408 .

Papuziński, A., 2006. Świadomość ekologiczna w świetle teorii i praktyki (Zarys politologicznego modelu świadomości ekologicznej). Problemy ekorozwoju, 1(1), 33-40.

Partanen-Hertell, M., Harju-Autti, P., Kreft-Burman, K. Pemberton, D., 1999. Raising EA in the Baltic Sea area. Helsinki, Finnish Environment Institute. The Finnish Environment 327.

Pisano, I., Lubell, M., 2017. Environmental behavior in cross-national perspective: A multilevel analysis of 30 countries. Environment and Behavior, 49(1), 31-58, https://doi.org/10.1177\%2F0013916515600494.

Poskrobko B., 2007. Zarządzanie środowiskiem, red. PWE. Warsaw.

Prévot-Julliard, A. C., Clavel, J., Teillac-Deschamps, P., \& Julliard, R., 2011. The need for flexibility in conservation practices: exotic species as an example. Environmental management, 47(3), 315-321, https://doi.org/10.1007/s00267-011-9615-6.

Rosa, C. D., Collado, S., Profice, C. C., 2018. Measuring Brazilians' environmental attitudes: A systematic review and empirical analysis of the NEP scale. Current Psychology, 1-12. 